\title{
PRELIMINARY STUDY OF ANTIBIOTIC RESISTANT ESCHERICHIA COLI IN HOSPITAL WASTEWATER TREATMENT PLANTS IN INDONESIA
}

\author{
Gabriel Andari Kristanto $^{1 *}$, William Koven ${ }^{1}$ \\ ${ }^{1}$ Department of Civil, Faculty of Engineering, Universitas Indonesia, Kampus UI Depok, \\ Depok 16424, Indonesia
}

(Received: September 2017 / Revised: September 2018 / Accepted: April 2019)

\begin{abstract}
The widespread uses of antibiotics have encouraged antibiotic resistant bacteria to develop and wastewater treatment plants (WWTPs) are believed to be hotspots for the dissemination of such bacteria. This research was conducted to ascertain the effect of WWTPs at a Jakarta public hospital on the prevalance of antibiotic resistant $E$. coli in three antibiotics, namely Meropenem, Ciprofloxacin and Cefixime, using the Kirby Bauer method. WWTPs apply activated sludge, polystyrene filtration, and chlorination to treat hospital wastewater. Raw wastewater was found to contain $4.6 \times 10^{4} \mathrm{CFU}$ E. coli with the percentage of antibiotic-resistant $E$. coli in Meropenem of $3.8 \%$, in Ciprofloxacin of $53.8 \%$, and in Cefixime of $56.3 \%$, while treated wastewater contained antibiotic resistant E. coli in Meropenem at the level of $20 \%$, in Ciprofloxacin of $60 \%$, and in Cefixime of $80 \%$ for $1.3 \times 10^{3}$ CFU E. coli. Hospital WWTPs increased the percentage of antibiotic-resistant $E$. coli. The $E$. coli becoming resistant to Meropenem, the Carbapenem class antibiotic known for its effectiveness in dealing with antibiotic-resistant bacteria.
\end{abstract}

Keywords: Antibiotics; Escherichia coli; Kirby Bauer; Resistant bacteria; Wastewater

\section{INTRODUCTION}

As more and more people move to the city, one inevitable consequence that needs to be faced is crowded living conditions with inadequate facilities and job opportunities, forcing people to live in poverty. Poverty brings problems with sanitation, malnutrition and infectious diseases, amongst others. According to the World Health Organization (WHO) and the United Nation Children's Fund (UNICEF), 700 million people have no access to drinking water (the majority in Africa), 200 million people face sanitation problems, and 1 billion people defecate in the open (WHO \& UNICEF, 2014).

In 2017, the Indonesian population has reached more than 260 million people, many of whom are concentrated in the capital Jakarta (World Population Review, 2018), which had a population of 10 million people and a density of approximately 15,000 people per $\mathrm{km}^{2}$. This dense population means the city faces problems similar ones faced by other populous cities, especially poverty, sanitation, access to drinking water, and infectious diseases (DKI Jakarta Bureau of Statistics, 2014).

Antibiotics are the key to treat diseases caused by bacteria in most countries, including Indonesia. A survey conducted by the Parent Care Foundation (Yayasan Orang Tua Peduli) revealed that in Indonesia $86.4 \%$ of cases of dengue fever and $74.1 \%$ of diarrhea were treated

\footnotetext{
*Corresponding author's email: andari@eng.ui.ac.id, Tel. +62-21-7270029, Fax. +62-21-7270028 Permalink/DOI: https://dx.doi.org/10.14716/ijtech.v10i4.776
} 
with antibiotics, even though such diseases can sometimes be treated just by resting or consuming vitamin C (Yayasan Lembaga Konsumen Indonesia, 2014). Antibiotics are used not only in medical treatment, but also in agriculture to protect high value crops from bacteria, in livestock to prevent diseases and to stimulate their growth, and in fisheries to prevent bacterial contamination (Kümmerer, 2009). From 2000 to 2010, global antibiotic consumption increased by $36 \%$, from 54 billion to 73 billion pills (Van Boeckel et al., 2014)

These numbers show that the widespread use of antibiotics has reached a critical point. It is the major cause of the emergence of antibiotic resistant bacteria (ARB). The former health minister of Indonesia stated that at least 12,209 cases of ARB have been found, which is estimated to increase to at least 6,935 new cases annually in the country (Suara Pembaharuan, 2011).

Antibiotic resistance is defined as the ability of bacteria to grow in certain concentrations of antibiotics which are designated to inhibit such growth. The minimum concentration of antibiotic to inhibit bacterial growth is defined as Minimum Inhibitory Concentration (MIC), which is determined by scientists by various experiments. Bacteria are considered to be resistant when the antibiotic concentration needed to inhibit their growth exceeds the MIC (Drlica \& Perlin, 2011).

Scientists are concerned that the growth of ARB will return us to the age before antibiotics had been discovered, when thousands of people died just because of small infections. Hence, it is very important to study the hotspots where ARB emerge, so that effective action can be taken to tackle the problem. One of these hotspots is wastewater treatment plants (WWTPs) (Rizzo et al., 2013).

A large amount of antibiotic residual is excreted from the human body. It is estimated that at least $70 \%$ of total antibiotics consumed are excreted without undergoing any changes (Kümmerer, 2009). The excreted antibiotics, having been reduced by the human metabolism, have a no-kill concentration, known as sub-inhibitor concentration. These antibiotics are mixed intensely with pathogenic bacteria in wastewater. The long journey begins from the wastewater collection system to the WWTPs. In WWTPs, more intense contact takes place: in no-kill concentration, bacteria absorb the antibiotics and begin to adapt to them, ultimately developing antibiotic resistant (Rizzo et al., 2013). At the final stage of the process, most WWTPs apply chlorination to ensure that all the microorganisms and viruses are destroyed. Seen as the key process in preventing the dissemination of $\mathrm{ARB}$, many researchers have, however, found this process to have low affectivity in dealing with the problem (Everage et al., 2014).

Eventually, the treated wastewater, which still contains partially changed antibiotics, ARB and Antibiotic Resistant Gen (ARG) from destroyed ARB, is discharged into a receiving water body. The partially-changed antibiotic will induce mutation, and ARG will make genetic transformation, making the antibiotic susceptible to indigenous bacteria in the receiving water and becoming ARB (Everage et al., 2014).

In Europe and the United States, research in antibiotic resistant dissemination has been developing. The research objects have ranged from antibiotic concentration to bacteria gen in urban wastewater (Birošová et al., 2014; Everage et al., 2014; Paulus et al., 2019). In Indonesia, there is a lack of research concerning WWTPs as hotspots for ARB dissemination, although there have been many recorded cases of ARB (MIMS Today, 2017). Some of the reasons why some countries have fallen behind others in research include lack of human resources, unavailable measuring instruments, and dilution of wastewater due to high water consumption per capita per day (Al-Maadheed et al., 2019). Research should therefore start with WWTPs, where tons of microorganisms have close contact with large amounts of antibiotics, confirming the presence of ARB dissemination in WWTPs.

Hospitals commonly use antibiotics to treat patients for various diseases. They experience a $25 \%$ higher antibiotic concentration than domestic WWTPs (Paulus et al., 2019). As a result, the contact 
between antibiotics and bacteria is more likely to happen at WWTPs owned by hospitals. This research aims to conduct a preliminary study of antibiotic resistant Escherichia coli in each unit of the waste water treatment plant at one of Jakarta's public hospitals. The hospital will hereinafter be referred to as RSX for confidentiality purposes.

\section{METHODS}

\subsection{Sampling Point}

The WWTP at RSX applied four processes in treating wastewater; which was a mixture of laboratory, medical and domestic wastewater. These were an equalization tank; a Fluidized Bed Biofilm Reactor (FBBR) - activated sludge; up-flow filtration; and chlorination. To analyze the effect of each process on bacteria resistance, influent and effluent from each process were collected and four sampling points were selected to meet needs. The first sampling point was the equalization tank, for the WWTP initial influent; the second was the surface of the sedimentation tank for activated sludge effluent; the third was from the filtration effluent pipe; and the fourth sampling point was from the treated water storage as the effluent of chlorination.

Using $500 \mathrm{~mL}$ amber glass bottles, two bottles of sample were collected at each sampling point on each sampling day. Samples were collected from September to November 2015 during the daytime.

\subsection{Sample Analysis}

The collected samples were placed in a cooler box, transported to the laboratory, and then tested for Chemical Oxygen Demand (COD), Biological Oxygen Demand (BOD), total E. coli colony, and percentage of antibiotic resistant $E$. coli in three antibiotics, Meropenem, Ciprofloxacin and Cefixime. The standards for COD and BOD testing were SNI 6989 (closed reflux and spectrophotometry) and SNI 6989.72:2009 (titrimetric) respectively. The total E. coli colony was tested using Total Plate Count (TPC), whiel antibiotic resistant $E$. coli was tested using the KirbyBauer method. The COD, BOD and total colony data were used to identify WWTP performance. A reduced concentration of COD, BOD or total colony throughout processes would indicate that they were running well, in order to justify the research as it was conducted at a well-performing WWTP.

The COD and BOD tests were performed on two out of four sampling times for each collected sampling bottle.

\subsection{Antibiotic Resistant E. coli Test}

To select $E$. coli from a variety of bacteria in the wastewater samples, they were inoculated at Brilliance E. coli (BEC). This has two chromogenic agents, Rose-gal and X-Glu. The function of Rose-gal is to detect $\beta$-galactosidase enzyme. Coliform bacteria will cleave Rose-gal by producing lactose enzyme and transform it into a pink-colored colony. On the other hand, E. coli will be distinguished from coliform, because this $E$. coli also produce glucuronidase enzyme, which is detected by X-Glu, giving the E. coli a purple color (Thermo Fisher Scientific, 2001).

The selected E. coli were grown in Tryptic Soya Agar (TSA). Before the bacteria were moved to Mueller Hinton Agar (MHA) for the antibiotic resistant test, the E. coli were standardized using $0.5 \mathrm{McFarland}$ Standard $\left(1.5 \times 10^{8} \mathrm{CFU} / \mathrm{mL}\right)$. The standardization was conducted to ensure that the bacteria inoculated in MHA had approximately the same total colony. Antibiotic discs were inserted after the E. coli had been inoculated in MHA. Each MHA petri dish was inserted with three different antibiotic discs, namely Meropenem, Ciprofloxacin and Cefixime. The antibiotic concentration in the Meropenem disc was $10 \mu \mathrm{g}$, for Ciprofloxacin it was $5 \mu \mathrm{g}$ and for Cefixime $5 \mu \mathrm{g}$. The E. coli were then incubated at $35^{\circ} \mathrm{C}$ for $18-24$ hours. Finally, the inhibition zones were measured using a ruler. Each of the measured zones was compared to the MIC antibiotic diameter inhibition zone to determine if the bacteria were resistant, intermediate or susceptible. 
As presented in Figure 1, 240 inhibition zones were measured for each sampling time, with each of the antibiotics having 80 zones. Each bottled sample was inoculated in two BEC, and five colonies of $E$. coli in each BEC were inoculated in TSA. From TSA the colony was put into solution that was then standardized. Finally, each TSA had one MHA with three antibiotic discs in it.

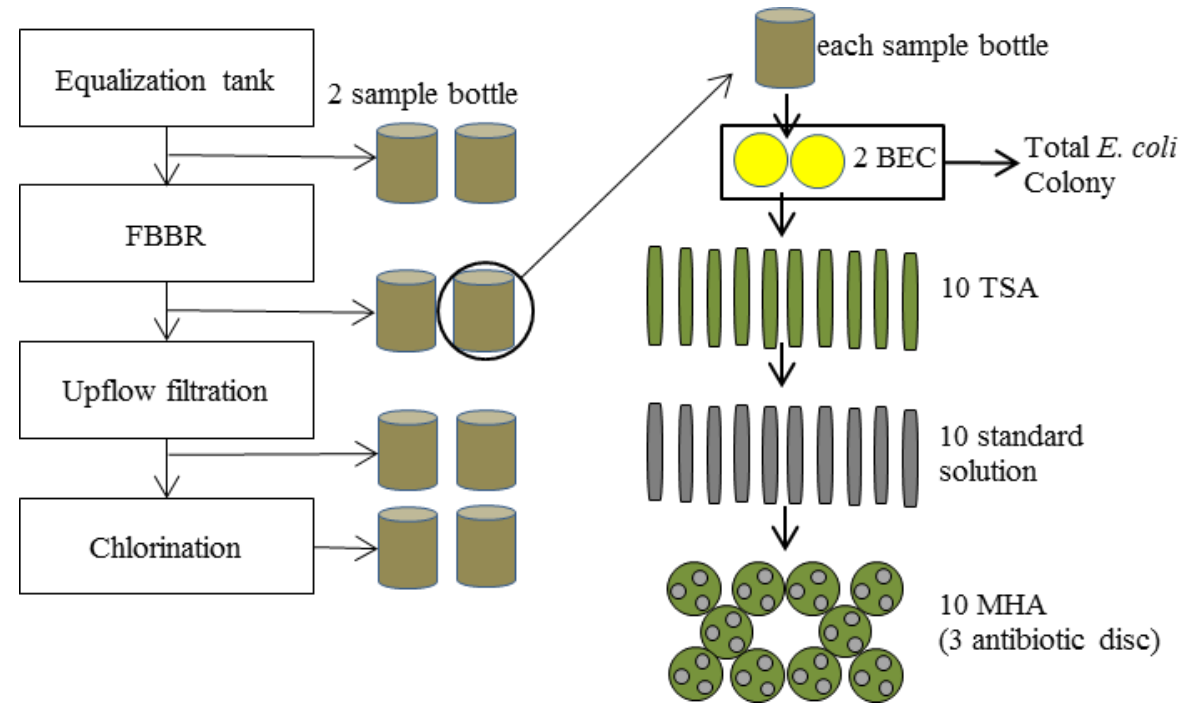

Figure 1 Antibiotic resistant $E$-coli analysis process

\section{RESEARCH METHODOLOGY}

\subsection{WWTP Performance}

Table 1 presents the average value of the COD and BOD at each sampling point on each sampling day. Each of the collected sample bottles on the sampling day was tested for both parameters. COD reduction was observed in the activated sludge unit, and removal reached more than $90 \%$ (Table 1). However, in the filtration process, the COD increased to $64 \mathrm{mg} / \mathrm{L}$, and in the chlorination effluent, it reached $65 \mathrm{mg} / \mathrm{L}$. This was because of the added chlorine in the chlorination process, which can be oxidized, increasing the level of detected COD (Sawyer et al., 2003). The detected BOD was proportional to the COD. In the WWTP influent and chlorination effluent, the BOD was unable to be tested. It is believed that the influent was dominated by toxic chemicals from the hospital laboratory and the chlorination effluent by chlorine. The BOD is a bioassay test, meaning nutrients for microorganism growth must be available and toxic compounds must be absent from the test sample (Sawyer et al., 2003). The COD and BOD effluent thresholds for hospital-generated wastewater are regulated by Republic of Indonesia Ministerial Decree of Environment No 58/1995 at $100 \mathrm{mg} / \mathrm{L}$ and $75 \mathrm{mg} / \mathrm{L}$, respectively (Kementerian Lingkungan Hidup, 1995). One of the tested CODs for chlorination effluent was $65 \mathrm{mg} / \mathrm{L}$, meaning RSX was complying with the regulation on discharging wastewater. However, on other occasion, the COD reached $351 \mathrm{mg} / \mathrm{L}$ filtration effluent, and the chlorination effluent was undetected, presumably due to high level of COD after chlorine had been added.

The E. coli colonies were reduced throughout the treatment process (Table 2). Beginning from the influent $4.6 \times 10^{4} \mathrm{CFU} / \mathrm{mL}$, the detected colonies were reduced through the treatment process until sometimes were they undetected in the chlorination effluent. The WWTP performance was difficult to analyzed based on the COD and BOD data, but combined with the TPC test, it can be confirmed that the WWTP ran well overall. 
Table 1 COD and BOD data

\begin{tabular}{llcc}
\hline $\begin{array}{c}\text { Sampling } \\
\text { Time }\end{array}$ & \multicolumn{1}{c}{ Sampling Point } & $\begin{array}{c}\text { COD } \\
(\mathrm{mg} / \mathrm{L})\end{array}$ & $\begin{array}{c}\text { BOD } \\
(\mathrm{mg} / \mathrm{L})\end{array}$ \\
\hline September & Influent & 406 & - \\
$29^{\text {th }} 2015$ & Activated Sludge Effluent & 39 & 1.54 \\
& Filtration Effluent & 64 & 5.41 \\
& Chlorination Effluent & 65 & - \\
November & Influent & 1151 & - \\
$10^{\text {th } 2015}$ & Activated Sludge Effluent & 32 & 8 \\
& Filtration Effluent & 351 & - \\
& Chlorination Effluent & - & - \\
\hline
\end{tabular}

Table 2 E. coli colony data

\begin{tabular}{lccccc}
\hline $\begin{array}{c}\text { Effluent } \\
\text { Process }\end{array}$ & $\begin{array}{c}\text { Sept } 8^{\text {th }} \\
(\mathrm{CFU} / \mathrm{mL})\end{array}$ & $\begin{array}{c}\text { Sept 29 } \\
(\mathrm{CFU} / \mathrm{mL})\end{array}$ & $\begin{array}{c}\text { Oct 27 } \\
(\mathrm{CFU} / \mathrm{mL})\end{array}$ & $\begin{array}{c}\text { Nov 10 } \\
(\mathrm{CFU} / \mathrm{mL})\end{array}$ & $\begin{array}{c}\text { Average } \\
(\mathrm{CFU} / \mathrm{mL})\end{array}$ \\
\hline Influent & $2.4 \times 10^{4}$ & $2.2 \times 10^{4}$ & $7.5 \times 10^{4}$ & $6.1 \times 10^{4}$ & $(4.6 \pm 2.9) \times 10^{4}$ \\
Activated & $3.5 \times 10^{3}$ & $4.1 \times 10^{3}$ & $8.5 \times 10^{3}$ & $3.9 \times 10^{3}$ & $(5.0 \pm 2.4) \times 10^{3}$ \\
Sludge & & & & & \\
Filtration & $2.0 \times 10^{3}$ & $2.4 \times 10^{3}$ & $3.7 \times 10^{3}$ & $1.2 \times 10^{3}$ & $(2.3 \pm 1.0) \times 10^{3}$ \\
Chlorination & $1.8 \times 10^{3}$ & 0 & 0 & $7.7 \times 10^{2}$ & $(6.4 \pm 8.1) \times 10^{2}$ \\
\hline
\end{tabular}

The constant decrease in $E$. coli colonies was not related to the fluctuating number of COD and BOD. Like this research, another study also found no relation between the presence of bacteria (in $\mathrm{CFU} / \mathrm{mL}$ ) and the metabolism of microorganisms (COD-BOD) in the treatment process (Ferreira da Silva et al., 2006).

\subsection{Antibiotic Resistant E. coli at the Hospital WWTP}

The colonies of E. coli were reduced through the treatment process. In fact, in the effluent from chlorination, no bacteria colony was found at two out of the four sampling times. However, problems appeared when the WWTP effluent still had E. coli and coliform in the effluent from the final treatment process. On September $8^{\text {th }}$ and November $10^{\text {th }} 2015$, the effluent was found to have $1.8 \times 10^{3} \mathrm{CFU} / \mathrm{mL}$ and $7.7 \times 10^{2} \mathrm{CFU} / \mathrm{mL}$ of E. coli respectively.

The detected $E$. coli was tested for antibiotic resistance, and the test showed that the percentage of antibiotic-resistant E. coli increased after the treatment process at the RSX WWTP. Table 3 shows the percentage increase in antibiotic-resistant $E$. coli in the influent and effluent of the hospital WWTP.

Table 3 Percentage increase in antibiotic resistance before and after the treatment process

\begin{tabular}{lcccccc}
\hline \multirow{2}{*}{$\%$ Resistance } & \multicolumn{3}{c}{ September $8^{\text {th }}$} & 2015 & \multicolumn{3}{c}{ November $10^{\text {th }}$} & 2015 \\
\cline { 2 - 7 } & MEM & CIP & CFM & MEM & CIP & CFM \\
\hline Influent & 0 & 35 & 25 & 5 & 55 & 70 \\
Effluent & 25 & 50 & 75 & 15 & 70 & 85 \\
\% Increase & 25 & 15 & 50 & 10 & 15 & 15 \\
\hline
\end{tabular}

MEM, CIP and CFM are used as abbreviations for Meropenem, Ciprofloxacin and Cefixime, respectively. Other studies support this research, having found that the WWTP process increases 
the percentage of ARB (Ferreira da Silva et al., 2006; Ferreira da Silva et al., 2007; Kim et al., 2014; Guo et al., 2015).

From the overall observed data, there was a high percentage of antibiotic resistant $E$. coli to Cefixime and Ciprofloxacin. Birošová et al. (2014) also found the same result from their research conducted in Slovakia's domestic WWTP using agar diffusion method. They found that the percentage of ARB to Ciprofloxacin could reach $74 \%$, with an average above $50 \%$.

Other research in the northern part of Portugal found a low percentage of antibiotic resistant Escherichia spp to Ciprofloxacin (Ferreira da Silva et al., 2007); Escherichia spp is a genus of E. coli species. The different results could have been caused by the concentration of antibiotics in the wastewater (Kim et al., 2014) and the different treatment process applied (Bouki et al., 2013; Rizzo et al., 2013).

Research in Cheongwon's domestic WWTP in Chungbuk, Korea, provided a very clear explanation of the effect of antibiotic concentration (Kim et al., 2014). It found that antibiotics help genetic transfer in sub-inhibitor concentrations $(10-100 \mathrm{ppb})$, but that they kill cells at a concentration of more than $100 \mathrm{ppb}$. It is believed that the concentration of antibiotics at the RSX WWTP was different to that in the North Portuguese WWTP. Besides, the treatment process applied and the source of the wastewater were different.

The percentage of antibiotic-resistant E. coli to Meropenem was observed to be less than $10 \%$ (Figure 2). Meropenem is a $\beta$-lactam class of the Carbapenem sub-category. Carbapenem is a special antibiotic designed to fight ARB, one of which is antibiotic-resistant $E$. coli. Unlike other $\beta$-lactam antibiotics, Carbapenem can resist the $\beta$-lactamase which is used by ARB to fight such an antibiotic. Unfortunately, another mechanism was developed by the bacteria to resist Carbapenem (Papp-Wallace et al., 2011) by producing Carbapenemase enzyme. The first resistance was found in 2008 (Drlica \& Perlin, 2011).

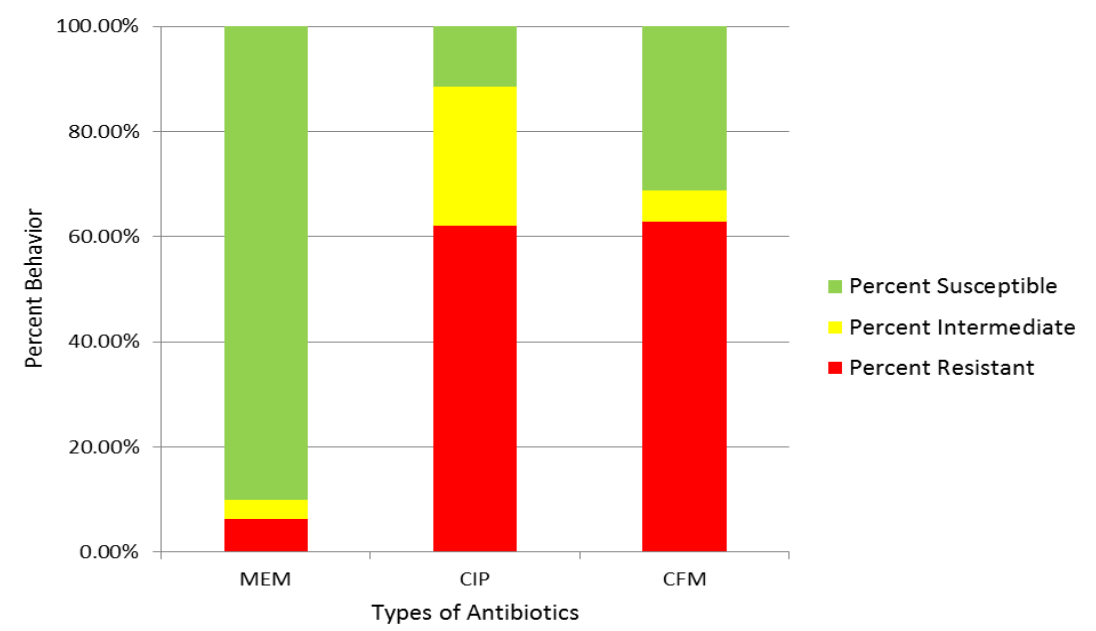

Figure 2 Percent behavior of $E$. coli after being exposed to Meropenem, Ciprofloxacin, and Cefixime

This research shows that the occurrence of Meropenem resistant bacteria are growing in Indonesia. The discharge of wastewater containing Meropenem resistant $E$. coli will induce gene transfer to indigenous bacteria, building their resistance to Meropenem (Kim et al., 2007; Szczepanowski et al., 2009; Novo et al., 2013; Kim et al., 2014; Guo et al., 2015; Tahrani et al., 2015).

Since this study only focused on E. coli, only a small proportion of ARB was covered. Guo et al. (2015) found that after going through the WWTP process, ARB become more diverse. Tahrani et al. (2015) found that even in treated wastewater from pharmaceutical WWTP, some pathogens 
such as Pseudomonas, Acinetobacter, Morganella, Shewanella, Delfia and Exiguobacterium were detected (Tahrani et al., 2015). The interesting part of their research is that the isolated bacteria in a bottle containing 3\% antibiotic could survive for three weeks, meaning that the bacteria harnessed the organic carbon in the antibiotic for its growth. This provides the opportunity to harness bacteria to degrade antibiotic traces and to prevent dissemination of the antibiotic, which may solve the ARB problem.

\subsection{Antibiotic Resistant E. coli in Activated Sludge}

In activated sludge, the percentages of antibiotic resistant E. coli were $1.4 \%, 59.7 \%$ and $65.3 \%$ for the antibiotics Meropenem, Ciprofloxacin and Cefixime respectively. Table 4 shows the percentage of antibiotic-resistant $E$. coli in the total $E$. coli in each unit of the treatment process. The numbers in parentheses show the percentage of intermediate bacteria, the bacteria which will grow to become ARB (Ferreira da Silva et al., 2006; Ferreira da Silva et al., 2007).

The TPC data show that the activated sludge process was able to remove E. coli from the wastewater stream, but the Kirby Bauer data show that the percentage resistance of E. coli also increased toward Ciprofloxacin and Cefixime. Parallel to this research, many other studies have also found that although activated sludge is able to remove bacteria, the percentage of ARB continues to increase (Ferreira da Silva et al., 2006; Ferreira da Silva et al., 2007).

A further study by Gou et al. (2015), who simulated the activated sludge process on a laboratory scale to understand the resistant profile to Erythromycin, found that the resistant profile increased after completing the activated sludge process (Guo et al., 2015). Their designed bioreactor had eight hours' retention time. They stated that the heterogeneous environment in activated sludge (diverse bacteria and nutrients inside) encouraged antibiotic-resistant genes to be transferred to new bacteria, resulting in an increased percentage of ARB within a short time. To confirm this hypothesis, they also analyzed the diversity of the bacteria, and found that the range became wider. Other researches conducted on bioreactors agree that the rich condition of antibiotics, bacteria and nutrients encourages the formation of ARB (Novo et al., 2013; Szczepanowski et al., 2009).

Table 4 Percentage antibiotic-resistant (intermediate) E. coli in each treatment process

\begin{tabular}{lccc}
\hline $\begin{array}{c}\text { \% Resistance } \\
\text { (intermediate) }\end{array}$ & MEM & CIP & CFM \\
\hline Influent & $3.8(3.8)$ & $53.8(35)$ & $56.3(6.3)$ \\
Activated Sludge & $1.4(1.4)$ & $59.7(26.4)$ & $65.3(5.6)$ \\
Effluent & & & \\
Filtration Effluent & $6.3(3.8)$ & $73.8(15)$ & $58.8(3.8)$ \\
Chlorination Effluent & $20(7.5)$ & $60(32.5)$ & $80(10)$ \\
\hline
\end{tabular}

\subsection{Antibiotic Resistant $E$. coli in Filtration}

In the filtration process, the average percentages of antibiotic-resistant $E$. coli were $6.3 \%, 73.8 \%$, and $58.8 \%$ to Meropenem, Ciprofloxacin and Cefixime respectively. Comparing to the data from the activated sludge effluent, the filtration process had no consistent effect on two of the antibiotics, Ciprofloxacin and Cefixime. Similarly, research conducted on the Eriskirch WWTP in Germany using diffuse agar found that the gravel filtration process consistently decreased the percentage of antibiotic resistant $E$. coli to profloxacin and Sulfamethoxazole, but not Erythromycin and Amphicilin (Lüddeke et al., 2015). Moreover, they found that sand or gravel filtration effectively reduced the percentage of $\mathrm{ARB}$, while a charcoal medium increased its percentage. 
Research conducted on Shanghai Water Treatment Plant (WTP) found that activated carbon increased the percentage of ARB (Bai et al., 2015). The research explained that at first the ARB formed a biofilm, leaving the wastewater stream. After a short time, the ARB biofilm encouraged ARG transfer to the bacteria in the wastewater stream. Research in a remote part of Canada examined the performance of filtration in removing nutrients, organic micro pollutants, antibiotics and ARG (Anderson et al., 2015). Their study mentioned that a filtering medium made of grass, soil, sand and gravel could effectively remove nutrient and micro pollutants, but had no effect on antibiotics. The ARG stuck to the filter medium and encouraged gene transfer after a long period of use. The backwash can also spread ARG to the environment.

\subsection{Antibiotic Resistant $E$. coli in Chlorination}

The average percentages of antibiotic-resistant E. coli to Meropenem, Ciprofloxacin and Cefixime in the effluent from chlorination or the final WWTP effluent were $20 \%, 60 \%$ and $80 \%$, respectively. Different to other treatments, chlorination is the prime disinfection process in removing bacteria (Everage et al., 2014). However, unfortunately the chlorination in this WWTP, which utilizes Trichloroisocyanuric acid (TCCA), increases the percentage of antibiotic resistant E. coli. in Meropenem and Ciprofloxacin, with the percentages of intermediate resistance and resistance clearly increasing after the chlorination process.

Research on a Shanghai WTP, which used chloramine in the disinfection process, found that Chloramine increased the percentage of ARB (Bai et al., 2015). According to the research, there is a possibility that ARB have more perfect structure body, making them become more resistant to oxidizers, disinfection and antibiotics than susceptible bacteria. Another research on a Nanjing WTP, which used chlorination, found that the process increased the percentage of ARB and ARG (Shi et al., 2012).

As disinfection is the prime process for removing bacteria, many previous studies were conducted to find the effective concentration to remove ARB. One study found that the effective concentration of sodium hypochlorite to remove $90 \%$ ARB was $30 \mathrm{mg} / \mathrm{L}$, with the highest removal rate occurring between 5 to $30 \mathrm{~min}$ contact time, and subsequently the removal rate was decreased (Zhang et al., 2015). In addition, it was also stated that the concentration of nitrogen ammonia hinders the removal process. Another study comparing the effective concentration of disinfectants to remove ARB and ARG found the moist effective concentration of chlorine and ozone to be $30 \mathrm{mg} / \mathrm{L}$ and $3 \mathrm{mg} / \mathrm{L}$, respectively (Oh et al., 2014).

Another study which aimed to find the effective CT (concentration and contact time) found that $50 \mathrm{mg} \mathrm{Cl} 2 \mathrm{~min} / \mathrm{L}$ was effective to remove all types of ARB (Huang et al., 2011). However, after comparing a low concentration $(2 \mathrm{mg} / \mathrm{L}$ Chlorine, $25 \mathrm{~min})$ and high concentration $(25 \mathrm{mg} / \mathrm{L}$ Chlorine, $2 \mathrm{~min}$ ), they concluded that high removal efficiency depended on a high concentration of around $25 \mathrm{mg} / \mathrm{L}$.

The RSX WWTP applied $10 \mathrm{mg} / \mathrm{L}$ chlorine with 15 minute contact time. Compared to other studies, this small concentration might be a problem; therefore, further research needs to be conducted. The concentration of ammonia in clean water is different to wastewater. Feces containing a high concentration of protein consists of an $\mathrm{N}$ cluster, which cannot be assimilated by the human body, with heterotrophic bacteria changing it to ammonia (Sawyer et al., 2003). A high concentration of ammonia can hinder the ARB removal process (Zhang et al., 2015).

\section{CONCLUSION}

The effect of hospital wastewater treatment plants on antibiotic resistant $E$. coli depends on the unit's process. Activated sludge increased by $4.17 \%$ the average of antibiotic-resistant $E$. coli due to its rich environment, which contains a wide variety of bacteria and nutrient. The filtration effect on antibiotic resistant $E$. coli depends on the filtration medium and the type of antibiotic. 
In the filtration process of this research, the average antibiotic resistant $E$. coli increase is $4.17 \%$, while on average chlorination increased antibiotic resistant $E$. coli by $7.03 \%$. Antibiotic resistant bacteria have a more perfect structure body, making them able to withstand disinfectants better than susceptible bacteria. Overall, the process in the hospital WWTP increased antibioticresistant E. coli by around $20 \%$.

\section{REFERENCES}

Al-Maadheed, S., Goktepe, I., Latiff, A.B.A., Shomar, B., 2019. Antibiotics in Hospital Effluent and Domestic Wastewater Treatment Plants in Doha, Qatar. Journal of Water Process Engineering, Volume 28, pp. 60-68

Anderson, J.C., Joudan, S., Shoichet, E., Cuscito, L.D., Alipio, A.E., Donaldson, C.S., Khanb, S., Goltz, D.M., Rudy, M.D., Frank, R.A., Knapp, C.W., Hansond, M.L., Wong, C.S., 2015. Reducing Nutrients, Organic Micropollutants, Antibiotic Resistance, and Toxicity in Rural Wastewater Effluent with Subsurface Filtration Treatment Technology. Ecological Engineering, Volume 84, pp. 375-385

Bai, X., Ma, X., Xu, F., Li, J., Zhang, H., Xiao, X., 2015. The Drinking Water Treatment Process as a Potential Source of Affecting the Bacterial Antibiotic Resistance. Science of the Total Environment, Volume 533, pp. 24-31

Birošová, L., Mackul'ak, T., Bodík, I., Ryba, J., Škubák, J., Grabic, R., 2014. Pilot Study of Seasonal Occurrence and Distribution of Antibiotics and Drug Resistant Bacteria in Wastewater Treatment Plants in Slovakia. Science of the Total Environment, Volume 490, pp. 440-444

Bouki, C., Venieri, D., Diamadopoulos, E., 2013. Detection and Fate of Antibiotic Resistant Bacteria in Wastewater. Ecotoxicology and Environmental Safety, Volume 91, pp. 1-9

Drlica, K., Perlin, D.S., 2011. Antibiotic Resistance: Understanding and Responding to an Emerging Crisis. New Jersey, USA: Pearson Education, Inc.

DKI Jakarta Bureau of Statistics, 2014. Jakarta in Number, Indonesia Central Bureau of Statistics, Jakarta, Indonesia. (in Bahasa)

Everage, T.J., Boopathy, R., Nathaniel, R., LaFleur, G., Doucet, J., 2014. A Survey of AntibioticResistant Bacteria in a Sewage Treatment Plant in Thibodaux, Louisiana, USA. International Biodeterioration \& Biodegradation, Volume 95(A), pp. 345-360

Ferreira da Silva, M., Tiago, I., Veríssimo, A., Boaventura, R.A.R., Nunes, O.C., Manaia, C.M., 2006. Antibiotic Resistance of Enterococci and Related Bacteria in an Urban Wastewater Treatment Plant. Federation of European Microbiological Societies Journal, Volume 55(2), pp. 322-329

Ferreira da Silva, M., Vaz-Moreira, I., Gonzalez-Pajuelo, M., Nunes, O.C., Manaia, C.M., 2007. Antimicrobial Resistance Patterns in Enterobacteriaceae Isolated from an Urban Wastewater Treatment Plant. Federation of European Microbiological Societies Journal, Volume 60(1), pp. $166-176$

Guo, M.T., Yuan, Q.B., Yang, J., 2015. Insights into the Amplification of Bacterial Resistance to Erythromycin in Activated Sludge. Chemosphere, Volume 136, pp. 79-85

Huang, J.J., Hu, H.Y., Tang, F., Li, Y., Lu, S.Q., Lu, Y., 2011. Inactivation and Reactivation of Antibiotic-Resistant Bacteria by Chlorination in Secondary Effluents of a Municipal Wastewater Treatment Plant. Water Research, Volume 45(9), pp. 2775-2781

Kementerian Lingkungan Hidup, 1995. Keputusan Menteri Negera Lingkungan Hidup No. 58 Tahun 1995 Tentang Baku Mutu Limbah Cair Bagi Kegiatan Rumah Sakit (Ministerial Decree of Environment of the Republic of Indonesia No 58/1995 Concerning Levels of Effluent Discharged and Restricts Concentration of Chemical and/or Metal Pollutants from Hospital Activities), Ministry of Environment, Indonesia (in Bahasa) 
Kim, S., Aga, D.S., Jensen, J.N., Weber, A.S., 2007. Effect of Sequencing Batch Reactor Operation on Presence and Concentration of Tetracycline-Resistant Organisms. Water Environment Research, Volume 79(11), pp. 2287-2297

Kim, S., Yun, Z., Ha, U.H., Lee, S., Park, H., Kwon, E.E., Cho, Y., Choung, S., Oh, J., Medriano, C.A., Chandran, K., 2014. Transfer of Antibiotic Resistance Plasmids in Pure and Activated Sludge Cultures in The Presence of Environmentally Representative Micro-Contaminant Concentrations. Science of the Total Environment, Volume 468-469, pp. 813-820

Kümmerer, K., 2009. Antibiotics in the Aquatic Environment - A Review - Part I. Chemosphere, Volume 75(4), pp. 417-434

Lüddeke, F., Heß, S., Gallert, C., Winter, J., Gude, H., Loffler, H., 2015. Removal of Total and Antibiotic Resistant Bacteria in Advanced Wastewater Treatment by Ozonation in Combination with Different Filtering Techniques. Water Research, Volume 69, pp. 243-251

MIMS Today, 2017. Semakin Memburuknya Kasus Resistensi Antibiotik di Indonesia (The Antibiotic Resistant Case is Worsening in Indonesia). Available Online at https://today.mims.com/semakin-memburuknya-kasus-resistensi-antibiotik-di-indonesia, Accessed on February 23, 2019 (in Bahasa)

Novo, A., Andre, S., Viana, P., Nunes, O., Manaia, C., 2013. Antibiotic Resistance, Antimicrobial Residues and Bacterial Community Composition in Urban Wastewater. Water Research, Volume 47(5), pp. 1875-1887

Oh, J., Salcedo, D.E., Medriano, C.A., Kim, S., 2014. Comparison of Different Disinfection Processes in the Effective Removal of Antibiotic-Resistant Bacteria and Genes. Journal of Environmental Science, Volume 26(6), pp. 1238-1242

Papp-Wallace, K.M., Endimiani, A., Taracila, M.A., Bonomo, R.A., 2011. Carbapenems: Past, Present, and Future. Antimicrobial Agents Chemotherapy, Volume 55(11), pp. 4943-4960

Paulus, G.K., Hornstra, L.C., Alygizakis, N., Slobodnik, J., Thomaidis, N., Medema, G., 2019. The Impact of On-site Hospital Wastewater Treatment on the Downstream Communal Wastewater System in Terms of Antibiotics and Antibiotic Resistance Genes. International Journal of Hygiene and Environmental Health, Volume 222(4), pp. 635-644

Rizzo, L., Manaia, C., Merlin, C., Schwartz, T., Dagot, C., Ploy, M., Michael, I., Fatta-Kassinos, D., 2013. Urban Wastewater Treatment Plants as Hotspots for Antibiotic Resistant Bacteria and Genes Spread into Environment: A Review. Science of Total Environment, Volume 447, pp. 345-360

Sawyer, C.N., McCarty, P.L., Parkin, G.F., 2003. Chemistry for Environmental Engineering and Science. New York, USA: McGraw-Hill

Shi, P., Jia, S., Zhang, X.X., Zhang, T., Cheng, S., Li, A., 2012. Metagenomic Insights into Chlorination Effects on Microbial Antibiotic Resistance in Drinking Water. Water Research, Volume 47(1), pp. 111-120

Suara Pembaharuan, 2011. Indonesia Ranked $8^{\text {th }}$ in World Antibiotic Resistant. Available Online at: $\quad$ http://sp.beritasatu.com/home/indonesia-peringkat-ke-8-kebal-obat-di-dunia/5414, Accessed on April 12, 2015 (in Bahasa)

Szczepanowski, R., Burkhard, L., Irene, K., Karl-Heinz, G., Tim, G., Wolfgang, E., Alfred, P., Andreas, S., 2009. Detection of 140 Clinically Relevant Antibiotic-Resistance Genes in The Plasmid Metagenome of Wastewater Treatment Plant Bacteria Showing Reduced Susceptibility to Selected Antibiotics. Microbiology, Volume 155, pp. 2306-2319

Tahrani, L., Soufi, L., Mehri, I., Najjari, A., Hassan, A., Loco, J.V., Reyns, T., Cherif, A., Mansour, H.B., 2015. Isolation and Characterization of Antibiotic-Resistant Bacteria from Pharmaceutical Industrial Wastewaters. Microbial Pathogenesis, Volume 89, pp. 54-61

Thermo Fisher Scientific, 2001. Dehydrated Culture Media: Brilliance E. coli/Coliform Selective Agar.

Available

Online 
http://www.oxoid.com/uk/blue/prod_detail/prod_detail.asp?pr=CM1046\&c=uk\&lang=EN \&org=71\&img=CM1046\&sec=, Accessed on April 25, 2015

Van Boeckel, T.P., Gandrea, S., Ashok, A., Caudron, Q., Grenfell, B.T., Levin, S.A., Laxminarayan, R., 2014. Global Antibiotic Consumption 2000 to 2010: An Analysis of National Pharmaceutical Sales Data. Lancet Infectious Disease, Volume 14(8), pp. 742-750 WHO, UNICEF, 2014. Progress on Drinking Water and Sanitation 2014 Update, WHO and UNICEF, Geneva, Swiss

World Population Review, 2018. Indonesia Population 2019. Available Online at http://worldpopulationreview.com/countries/indonesia-population/, Accessed on February 19,2019

Yayasan Lembaga Konsumen Indonesia, 2014. Kasus Resistensi Bakteri Semakin Tinggi, Berhati-hatilah Memakai Antibiotik! (Antibiotic Resistant Bacteria Cases is Rising, Be Considerate in Using Antibiotic!). Available Online at http://ylki.or.id/2014/04/kasusresistensi-bakteri-semakin-tinggi-berhati-hatilah-memakai-antibiotik/, Accessed on April 12, 2015 (in Bahasa)

Zhang, Y., Zhuang, Y., Geng, J., Ren, H., Zhang, Y., Ding, L., Xu, K., 2015. Inactivation of Antibiotic Resistance Genes in Municipal Wastewater Effluent by Chlorination and Sequential UV/Chlorination Disinfection. Science of the Total Environment, Volume 512513, pp. 125-132 